\title{
Lymphatic deseases: geriatrical epidemiological data: the role of rehabilitation
}

\author{
M Ricci $^{1 *}$, L Sandroni ${ }^{2}$ \\ From de Senectute: Age and Health Forum \\ Catanzaro, Italy. 5-7 December 2009
}

\section{Background}

In 1994 the WHO showed about 140 millions cases of lymphedema (Table 1).

Italian epidemiological studies report that primary lymphedema are more frequent than secondary. The localization of upper limbs recognizes secondary lymphedema; the primary ones can be located in lower limbs. 30-40 y.o. women are more exposed.

In geriatric patients lymphedema is generally secondary and concerned with upper limbs (Mastectomy). In lower limbs it follows cervix carcinoma treatments (46\%), urologic diseases (39\%), melanoma treatments (6\%), Hodgkin lymphoma (3\%), venous failures etc.

In geriatric patients lymphedema disabilities make previous pathologies worse and rehabilitative therapies are recommended.

\section{Materials and methods}

In UO Medicina Riabilitativa, Ospedali Riuniti Ancona, Lymphedema is treated throught a Rehabilitative Project performed by a Team.

The treatments are concerned with patient's impairments and disabilities, according to ICF.

\section{Results}

In 2008, 83 new patients have been examined. 10 males and 73 females. Mean age 57,7 y.o.

\section{Table 1 Statistics WHO 1994}

\begin{tabular}{ll}
\hline Statistics WHO 1994 & \\
\hline Total Lymphedema & $140 \mathrm{Ml}$ \\
Primary Lymphedema & $70 \mathrm{Ml}$ \\
Parasitic origin (F.B.) & $40 \mathrm{Ml}$ \\
Secondary Lymphedema & $20 \mathrm{Ml}$ \\
Functional Problems (CVD) & $10 \mathrm{Ml}$ \\
\hline
\end{tabular}

${ }^{1}$ Rehabilitative Medicine, Ospedali Riuniti Ancona

25 Lymphedema in over 65 y.o. patients: 24 secondary and 1 primary. The secondary were: 44 post-mastectomy; 21 post surgical operation on pelvis or lower limbs; 8 after CVD; 1 post-radiotherapy; 1 post erysipelas. Tables 2, 3 and 4

\section{Conclusions}

This statistics show that in geriatric patients lymphatic system pathologies are often related both to CVD and to surgery (pelvis operations) with inguinal, iliac and lumbar aortic nodes removal.

\section{Table 2 Statistics}

Statistics

$\begin{array}{ll}\text { Total patients } & 83 \\ & \\ \text { Primary Lymph. } & 8 \\ \text { Secondary Lymph. } & 75 \\ \text { Mean Age } & 57,7\end{array}$

Table 3

\begin{tabular}{lll}
\hline & Total patients & over $\mathbf{6 5}$ y.o. \\
\hline Post-Mastectomy & 44 & 14 \\
Post-Surg. L.L. & 21 & 4 \\
Post-CVD & 8 & 5 \\
Post-eresypelas & 1 & 1 \\
Post-Radiotherapy & 1 & 0 \\
\hline
\end{tabular}

Table 4

\begin{tabular}{ll}
\hline Over 65 y.o. & $\mathbf{2 5}$ \\
\hline & $\begin{array}{l}\text { secondary Lymphedemas } 24 \\
\text { primary Lymphedema } 1\end{array}$ \\
\hline
\end{tabular}




\section{Author details}

${ }^{1}$ Rehabilitative Medicine, Ospedali Riuniti Ancona. ${ }^{2}$ School of Medicine,

Università Politecnica Marche, Ancona.

Published: 19 May 2010

\section{References}

1. Antignani $P L$, et al: L'insufficienza venosa cronica: risultati di un'indagine epidemiologica in Italia. /l quaderno della Flebologia. 2006.

2. Michelini S, et al: Epidemiologia del linfedema. Auxilia-Linfologia 1998.

3. Gasbarro V, Michelini S, Antignani PL, Tsolaki E, Ricci M, Allegra C: The CEAP-L classification for lymphedemas of the limbs: the Italian experience. Internationale Angiology 2009, 28(24):315-324.

4. Ricci M: Proposal of Disability Scale for Lymphoedema. Eur J Lymphol 2008, XIX(55).

5. World Health Organization: International Classification of Functionng, Disability and Health. WHO 2001.

doi:10.1186/1471-2318-10-S1-A113

Cite this article as: Ricci and Sandroni: Lymphatic deseases: geriatrical epidemiological data: the role of rehabilitation. BMC Geriatrics 201010 (Suppl 1):A113.

\section{Submit your next manuscript to BioMed Central} and take full advantage of:

- Convenient online submission

- Thorough peer review

- No space constraints or color figure charges

- Immediate publication on acceptance

- Inclusion in PubMed, CAS, Scopus and Google Scholar

- Research which is freely available for redistribution

Submit your manuscript at www.biomedcentral.com/submit 